\title{
Measuring race and ethnicity in the censuses of Australia, Canada, and the United States: Parallels and paradoxes
}

\author{
Gillian Stevens ${ }^{1}$ \\ Hiromi Ishizawa \\ Douglas Grbic
}

\begin{abstract}
Most national censuses include questions about race, colour, national origins, ethnicity, ancestry, and tribe in an effort to describe subgroups within their population. In this paper, we focus on changes over the last half-century in the racial and ethnic classification schemes of the censuses in three countries that share important historical and demographic features-Australia, Canada, and the United States. We show that there are similarities, as well as some idiosyncratic features, in how these three nations define and describe racial and ethnic subgroups. We then argue that the gathering of data on the racial/ethnic subgroups in these three nations has followed a similar progression over the last half-century because of shifts in the understanding of race and ethnicity, data-gathering procedures, and the ongoing dialogue between each national population and its data-gathering institution.
\end{abstract}

Keywords: census; measurement; race; ethnicity.

\section{Résumé}

La plupart des recensements nationaux incluent des questions sur la race, la couleur, les origines ethniques, l'ascendance et la tribu dans le but de décrire les sous-groupes de la population. Dans cet article, nous ciblons les changements des cinquante dernières années dans les schémas de classification raciale et ethnique des recensements de trois pays, à savoir l'Australie, le Canada et les États-Unis, qui partagent tous d'importantes caractéristiques sur le plan historique et démographique. Nous démontrons qu'il existe des similarités et des caractéristiques idiosyncratiques dans la manière dont ces trois pays définissent et décrivent les sous-groupes raciaux et ethniques. Nous faisons ensuite valoir que la collecte de données sur les sous-groupes raciaux et ethniques dans ces trois pays a suivi une progression semblable au cours des cinquante dernières années en raison de modifications dans la compréhension de race et d'ethnie, des méthodes de collecte des données et des dialogues en cours entre chaque population nationale et l'institution qui collecte les données.

Mots clés : recensement, mesure, race, ethnie.

\section{Introduction}

Most contemporary national censuses include one or more questions designed to describe subgroups within their populations, although the questions and terminology used (United Nations 2011) vary considerably across country and region. Terms such as race, colour, nationality, ethnicity, ancestry, ori-

1. Gillian Stevens, Director, Population Research Laboratory, Department of Sociology, University of Alberta, Edmonton AB Canada T6G 2H4. Email: gillian.stevens@ualberta.ca; Hiromi Ishizawa, George Washington University, Department of Sociology, Phillips Hall 409, 801 22nd Street NW, Washington, DC 20052, USA; and Douglas Grbic, Association of American Medical Colleges, 655 K Street NW, Washington, DC 20001. 
gins, and tribe appear in almost two-thirds of the mid-1990s to early 2000s censuses surveyed by Morning (2008). The United Nations (2011) argues that it is impossible to even suggest an internationally standardized set of questions or terms because each nation faces a different set of subgroups that it needs to identify. The description of the subgroups within a country that has or is experiencing immigration is made even more difficult, since the in-migration of new groups of people can change how racial and ethnic groups are defined and which ones are considered to be important to distinguish.

In this paper, we focus on changes over the last half-century in the racial and ethnic classification schemes in three countries that share some important demographic and historical features-Australia, Canada, and the United States. These shared features include a history of sustained immigration from Europe, followed by migration from other countries in the latter part of the 20th century, into lands occupied by indigenous peoples, as well as the fact that their census questionnaires are presented in the English language. We show that there are important similarities in how these three nations define and describe subgroups with immigrant origins ${ }^{2}$ in their general populations, although each country's series of censuses does include idiosyncratic features. We argue that the nations encountered similar problems in the gathering of data describing the racial/ethnic origins of their populations and often applied parallel solutions. The resulting similar shifts in the features of the official racial and ethnic data attended changes in the understanding of race, advances in procedures used in data gathering, and ongoing conversations between the national populations and their respective data-gathering institutions.

\section{Conceptualizations of race, origins, and ethnicity}

Although scholars consider race to be a socially constructed concept and without scientific underpinning, popular understandings of race place varying emphases on biological innateness or essentialism, cultural attributes, and identity (e.g., Morning 2009, 2011). Biological essentialism implies that a person's race is determined by his or her parents' race, and that a person's race can often be identified by phenotypic markers such as hair texture, eye shape, and skin colour. This approach leads to the conclusion that there are a limited number of races in the world and that people can easily distinguish members of one race from members of another. Thus, in this approach, a person's race is inherited or determined by ancestry, and identification of his or her race, by that person and by others, is obvious.

Relying on cultural attributes such as languages spoken and religious affiliations to distinguish subgroups from one another, on the other hand, implies that ethnicity is a socially acquired characteristic. Because cultural attributes often are (or were) linked to country of birth, this approach often slides into using national origins or political affiliations as the primary means of distinguishing subgroups from one another.

A third approach relies on the choices and assignments made by individuals, social institutions, or the state. Racial and ethnic group membership can be assigned using rules of inheritance, or through rules describing behaviours, such as speaking a specific language as a mother tongue. Individuals may self-identify as members of a specific subgroup, or be identified by the state, social institutions, or other individuals as members of a subgroup. And of course, referring to the two abovementioned

2. The indigenous peoples in the three nations include the Aboriginal people and Torres Strait Islanders in Australia, the First Nations, Métis, and Inuit peoples in Canada, and the Native Americans and Alaska Natives in the United States. We do not include a comparative discussion of the issues surrounding the enumeration of these subpopulations in their respective nations' censuses, because the complexity of the groups' social and political and histories demands separate treatment. 
Stevens et al.: Measuring race and ethnicity in the censuses of Australia, Canada, and the United States

conceptualizations, an ethnic self-declaration or an ethnic identification imposed by others may rest on criteria related to ancestry (biological) or some cultural (social) characteristic.

Which of these several approaches to the measurement of race and ethnicity is emphasized or referenced in a national census varies across time, place, situation, and nation (Kertzer and Arel 2002). The measurement of race in any national census is a product of the predominant contemporaneous understanding of race, as well as aspects of the nation's history. The result is that race and ethnicity are measured differently in censuses across the world's nations. Moreover, census measures of race and ethnicity change across time in any one country, because of changes in the understanding of notions of ethnicity and race, changes in survey technology, and - among immigrant-receiving nations-changes in the national origin of subgroups represented in the nations' general populations.

\section{Race and ethnicity in the national censuses of Australia, Canada, and the US}

Australia, Canada, and the United States share important demographic features. All three territories were inhabited by native peoples before the arrival of Europeans. All three experienced high rates of immigration during the 18th and 19th centuries from European nations, with the first major wave or waves of immigrants being from the United Kingdom. As a result, all three countries became largely English-speaking. During the 19th century and well into the 20th century, all three nations restricted migration from non-European nations in some way, with especially severe restrictions on the in-migration of people from Asian countries. All three nations then experienced high, albeit fluctuating, rates of immigration during the 20th century, and in all three nations, changes in immigration legislation in the latter half or third of the century allowed persons from non-European countries to more freely enter the country. As a result, immigration flows to each of the three countries in the last portion of the 20 th century and the first decade of the 21 st century included large contingents of immigrants from some combination of Asia, Latin America, and Africa.

The three nations thus share important similarities in the subgroups of their populations. The general population in each includes one or more indigenous peoples, large subgroups of people descended from the early European settlers, and relatively large and increasing numbers of people and their immediate descendants from other parts of the world.

All three countries were fielding national censuses by the late 19th century in order to gather information about their populations, and each has a long history of data collection on race and ethnicity. Australia started gathering information on race in 1911; Canada has gathered information on race or origins since 1767 (with the exception of 1891); and the United States has gathered information on race or slave status and origins since 1790. During the latter half of the 20th century, the censuses of the three countries used a wide variety of questions designed to measure racial and ethnic subgroups in their populations. At various times, the censuses have included direct queries about race that rest on notions of ancestry, queries about social and cultural attributes that are presumed to identify race or ethnicity, and queries about race and ethnicity that ask people to identify their own racial or ethnic affiliation. Then, in the 1970s each of the countries moved towards establishing a selfconscious set of standards for the measurement of race and ethnicity of their respective populations.

\section{Australia}

For most of the 20th century, Australian censuses included an explicit race or racial origin question. After 1976, however, the Australian Bureau of Statistics (ABS) deleted the racial origin question 
Table 1. Questions related to race and ethnicity in the Australian, Canadian, and US censuses, $1950 \mathrm{~s}-2010 / 11$.

\begin{tabular}{|c|c|c|c|}
\hline Census year $^{\mathrm{a}}$ & Australia & Canada & United States \\
\hline $1950 / 51$ & - & Origin & Race \\
\hline \multirow[t]{4}{*}{1954} & Religion & \multirow[t]{4}{*}{ - } & \multirow[t]{4}{*}{ - } \\
\hline & Birthplace & & \\
\hline & Year of arrival & & \\
\hline & Race & & \\
\hline 1956 & - & No question & - \\
\hline \multirow[t]{4}{*}{$1960 / 61$} & Religion & \multirow{4}{*}{$\begin{array}{l}\text { Ethnic/cultural group } \\
\text { ancestry }\end{array}$} & \multirow[t]{4}{*}{ Race } \\
\hline & Birthplace & & \\
\hline & Year of arrival & & \\
\hline & Race & & \\
\hline 1966 & Same as 1961 & No question & - \\
\hline \multirow[t]{5}{*}{$1970 / 71$} & Religion & \multirow{5}{*}{$\begin{array}{l}\text { Ethnic/cultural group } \\
\text { ancestry }\end{array}$} & Race \\
\hline & Birthplace & & \multirow[t]{4}{*}{ Origin or descent (long form) ${ }^{b}$} \\
\hline & Birthplace of parents & & \\
\hline & Year of arrival & & \\
\hline & Racial origin & & \\
\hline 1976 & Same as 1971 & No question & - \\
\hline \multirow[t]{7}{*}{$1980 / 81$} & Religion & \multirow{7}{*}{$\begin{array}{l}\text { Ethnic/cultural group } \\
\text { ancestry }\end{array}$} & Race \\
\hline & Birthplace & & Hispanic origin \\
\hline & Birthplace of parents & & Ancestry (long form) ${ }^{\mathrm{b}}$ \\
\hline & Year of arrival & & \\
\hline & Indigenous status & & \\
\hline & Language spoken & & \\
\hline & English proficiency & & \\
\hline 1986 & Same as 1981 , plus Ancestry question & Same as 1981 & - \\
\hline \multirow[t]{7}{*}{$1990 / 91$} & Religion & \multirow{7}{*}{$\begin{array}{l}\text { Ethnic/cultural group } \\
\text { ancestry } \\
\text { Aboriginal } \\
\text { Registered/Treaty Indian }\end{array}$} & Race \\
\hline & Birthplace & & Hispanic origin \\
\hline & Birthplace of parents & & \multirow[t]{5}{*}{ Ancestry (long form) ${ }^{b}$} \\
\hline & Year of arrival & & \\
\hline & Indigenous status & & \\
\hline & Language spoken & & \\
\hline & English proficiency & & \\
\hline 1996 & Same as 1991 & Same as 1991, plus & - \\
\hline & & Visible minority & \\
\hline \multirow[t]{8}{*}{$2000 / 01$} & Religion & \multirow{2}{*}{$\begin{array}{l}\text { Ethnic/cultural group } \\
\text { ancestral origins }\end{array}$} & \multirow{8}{*}{$\begin{array}{l}\text { Race } \\
\text { Hispanic origin } \\
\text { Ancestry (long form) }\end{array}$} \\
\hline & Birthplace & & \\
\hline & Birthplace of parents & Visible minority & \\
\hline & Year of arrival & Aboriginal & \\
\hline & Indigenous status & Indian Band/First Nation & \\
\hline & Language spoken & \multirow[t]{3}{*}{ Treaty or Registered Indian } & \\
\hline & English proficiency & & \\
\hline & Ancestry & & \\
\hline 2006 & Same as 2001 & Same as 2001 & - \\
\hline \multirow[t]{8}{*}{$2010 / 11^{c}$} & Religion & \multirow{8}{*}{$\begin{array}{l}\text { Ethnic/cultural group } \\
\text { ancestral origins } \\
\text { Visible minority } \\
\text { Aboriginal } \\
\text { Indian Band/First Nation } \\
\text { Treaty or Registered Indian }\end{array}$} & \multirow{8}{*}{$\begin{array}{l}\text { Race } \\
\text { Hispanic origin } \\
\text { Ancestry (American } \\
\text { Community Survey) }\end{array}$} \\
\hline & Birthplace & & \\
\hline & Birthplace of parents & & \\
\hline & Year of arrival & & \\
\hline & Indigenous status & & \\
\hline & Language spoken & & \\
\hline & English proficiency & & \\
\hline & Ancestry & & \\
\hline
\end{tabular}

a - During this time period, Australian censuses were fielded years ending in ' 1 ' or ' 6 ' (after the1950s); Canadian censuses were fielded in years ending in ' 1 ' or ' 6 '; and the US censuses were fielded in years ending in ' 0 '.

b - Between 1950 and 2000, there were often several versions of the general population census schedules in the US, with a longer form gathering data from a subsample of households.

c - In Canada, information previously collected by the mandatory long-form census questionnaire was collected as part of the new voluntary household survey (NHS). 
Stevens et al.: Measuring race and ethnicity in the censuses of Australia, Canada, and the United States

because the public reacted negatively to the word "racial" (Evans et al. 1993). Meanwhile, starting in 1954, the ABS gradually added questions to each succeeding census to serve as indirect measures of ethnicity. The 1954 census (the first post-WWII census) included three indirect measures of ethnicity: religious denomination, birthplace, and year of arrival in Australia. The 1971 census added the birthplaces of father and mother; the 1981 census added indigenous status, language spoken, and English proficiency; and the 1986 census added ancestry (see Table 1).

The movement away from an explicit race question toward the measurement of social and cultural origins in Australia was clearly articulated in the Borrie Report, which assessed the results of testing six alternative ethnicity questions in 1983 and 1984 (ABS 1984). The report outlined two strategies for measuring Australia's ethnic diversity: the use of "surrogates as ethnicity measures" and/or the inclusion of a direct ethnicity question of either the "ancestry" type or "self-identification" type (ABS 1984:7). A key recommendation of the report was for the national census to include, along with surrogate measures, a simply worded ancestry question: "What is each person's ancestry?" The ancestry question was included in the 1986 census, but an examination of the responses found that it did not adequately measure the ethnic characteristics of the Australian population (Kunz and Costello 2003). The ancestry question was therefore dropped after 1986, but it was reintroduced in 2001 because of user demand (ABS 2002: 10; Kunz 2003; Khoo and Lucas 2004).

\section{Canada}

Before 1951, the Canadian censuses included explicit questions asking about the race of the general population. However, as in Australia, an increased sensitivity after WWII to the implications of viewing race as primarily a biologically determined attribute resulted in a switch from explicit questions about race to questions about "origins" (see Table 1). Nevertheless, paralleling Australia's approach, Canada's new questions on origins still emphasized ancestry (thus evoking the biological rather than cultural or identificational dimension of race) by asking for the ethnic or cultural group that the person or his or her male ancestor belonged to at the time of arrival on the North American continent. The response categories varied somewhat from year to year, but included European nationalities and subnationalities, (e.g., "Finnish" and "Manx" in 1951), religious categories, (e.g., "Jewish" in 1971), overtly racial categories (e.g., "Negro" in 1961), as well as options for the native peoples (e.g., "Inuit" in 1981).

In 1996, the Canadian census schedule also included a new and extensively tested question designed to measure membership in a "visible minority" group (Boyd et al. 2000). Before 1996, visible minorities were not self-identified on the census schedules; instead, their status was imputed by Statistics Canada through a combination of answers to questions on language and origins. Statistics Canada included the explicit question on visible minority status, because the information gathered from the "ethnic/cultural question could no longer be considered reliable to provide sufficient information to identify the various groups comprising the visible minority population because of the increased reporting of "Canadian" only" (Statistics Canada 1998).

Although the new question does not explicitly mention the word "race," the definition of visible minority does. The inclusion of this question was a reaction to the 1995 Employment Equity Act, in which "visible minorities" were defined as "persons other than Aboriginal persons, who are nonCaucasian in race or non-White in colour" (Department of Justice 1995: 2). Visible minority groups in Canada are considered to include Blacks, South Asians, Chinese, Koreans, Japanese, Southeast Asians, Filipinos, Arabs and West Asians, and Latin Americans and Pacific Islanders. With the introduction of this new question on visible minority, and Statistics Canada's move away from imputing racial designations, the responsibility for assigning a racial category shifted from the state to the individual. 


\section{United States}

In the United States, information on race has been collected, directly or indirectly, since the first census was fielded in 1790 (US Census Bureau 2002). Since then, there have been many changes in the ways that race information is collected (see Lee 1993 for a discussion of changes until the 1990 census). One of the most important changes, which occurred in 1970, was a shift from relying on enumerators to observe and record a person's race to respondents self-identifying their race. As in Australia and Canada, this shift resulted in the state (or its representatives) abdicating its authority to assign racial characteristics in the census, thereby shifting the responsibility onto the shoulders of the respondents.

In 1977, the Office of Management and Budget (OMB) produced the "Statistical Policy Directive No. 15, Race and Ethnic Standards for Federal Statistics and Administrative Reporting," which proposed the use of a minimum of four race categories and a Hispanic origin category (OMB 1977). The directive was revised in 1997 to include a fifth racial category, Native Hawaiian or Other Pacific Islander, and to allow individuals to choose more than one category (OMB 1997). These standards were mainly developed to meet the needs of civil rights enforcement.

Before 1980, the Hispanic/Latino population had been identified in various ways. "Mexican" was included among the race categories in the 1930 census, but was discontinued after Mexican-Americans objected. In 1970, Hispanics were identified through mother tongue, place of birth, and surname questions in the long form sent to 15 per cent of US households (Snipp 2003). Although the origin or descent question did not use the words "Hispanic" or "Latino," the possible responses included "Mexican," "Puerto Rican," "Cuban," "Central American" or "South American," "Other Spanish," or "None" of them. The 1980 census included a separate question on Hispanic origins, and since then, the US Census Bureau has followed a two-question format for the collection and reporting of data on race and Hispanic origin. In 1980, it also added a third ethnicity-related question that addressed ancestry.

Thus, the three countries have approached the measurement of race and ethnicity in very different ways. Australia moved away from a direct query on race to using a set of social and cultural characteristics to measure ethnicity. Canada focused on ethnic or national origins until the 1980s, but then added a "visible minority" question in 1996 with response categories that look very much like racial groupings. The United States censuses have always included a direct query about race, an explicit Spanish-origin or Hispanic origin questions on the short form (from 1980 on), and a separate question on ancestry in the long forms (from 1980 to 2000) and in the American Community Survey (from 2000 on).

\section{Parallel problems across the censuses in the measurement of race and ethnicity}

In spite of these apparently stark differences in how the three nations measured race and ethnicity, the common demographic history of the three countries set the stage for some commonalities in the measuring of race and ethnicity of the subgroups of their respective populations. In all three countries, personnel in the census offices and the general population had difficulties in presenting and answering questions about the concepts of race and ethnicity, and in determining rules of inclusion in one group versus another. Demographic processes such as immigration and intermarriage made the measurement of race and ethnicity ever more complex. In addition, after each country shifted the responsibility for describing ethnic and racial characteristics to the respondents, each of the countries' census offices had to contend with growing numbers of people who could not, or would not, respond to the selected questions or use the official response categories provided. 
Stevens et al.: Measuring race and ethnicity in the censuses of Australia, Canada, and the United States

\section{Confusion and conflation surrounding race, ethnicity, origins, nationality, and cultural attributes}

All three countries, by virtue of their shared European roots, began the 20th century with an understanding that racial groups were closely tied to nations. As a result, the listed responses to questions on race in early censuses often explicitly referred to nationalities. However, by the middle of the 20th century, the link between race and nationhood had weakened as the understanding of race began to move away from biological essentialism to separate the ties between nation and race, and to incorporate the belief that race and its cousin, ethnicity, are culturally and socially defined and thus contextually specific. Still, many respondents and enumerators in the second half of the century continued to conflate race with national descent. For example, Canada's Dominion Bureau of Statistics (today Statistics Canada) valiantly and persistently strove to train its census enumerators to distinguish between citizenship, nationality, race, and "ethnic or cultural" group. As the Bureau noted in its instructions to enumerators from 1950 through 1971,

It is important to distinguish carefully between "citizenship" or "nationality" on the one hand and

"origin" on the other. Origin refers to the cultural group sometimes erroneously called "racial"

groups, from which the person is descended (Dominion Bureau of Statistics 1961: 33).

After Canada's censuses switched from primarily using enumerators to using mail-in/mail-back census schedules in 1971, the statistics office then turned its attention to training the general public to distinguish ethnic origins from citizenship or nationality. But the difficulties persisted. In a gentle and somewhat resigned acknowledgement that the general public apparently still did not fully understand the distinctions among these concepts, the instructions for the "ethnic origin" question in the 1991 Canadian census began with:

Ethnic or cultural origin refers to the ethnic "roots" or ancestral background of the population, and should not be confused with citizenship or nationality (Statistics Canada 1991).

In the US, which maintained an overt race question in its censuses stretching over the entire 20th century, the difficulties in measuring "race," and the overlap between race and nationality, were acknowledged forthrightly, although the US Census Bureau lay the responsibility for the conflation at the feet of the public:

fThe concept of race as it has been used by the [US] Bureau of the Census is derived from that which is commonly accepted by the general public. It does not, therefore, reflect clear-cut definitions of biological stock, and several categories obviously refer to nationality (US Census Bureau 2002: 35).

Although the US Census Bureau stated that it was the public's perception of race that drove the racial categories, in fact the Bureau placed the responsibility for determining the racial membership of Americans on census enumerators until 1970. Enumerators were to determine racial membership by observing the respondents rather than asking them directly, and the Census Bureau deemed their observations adequate. Without a clear definition of race, or any guidelines for determining boundaries between the races, the racial classification scheme ran into trouble, especially after the 1970 census, which relied on respondents to answer the race question on the census schedule.

Persons of Mexican or Latin descent, for example, were supposed to be classified as "white" in 1950 and 1960 "unless obviously of some non-white race" (US Census Bureau 2002: 35). Moreover, the official positioning of some racial boundaries seemed to be strongly influenced by who was on what committee. In 1975, for example, an ad-hoc Census Bureau committee decided that South Asians were "Caucasian, although frequently of a darker skin color" (Hattam 2007: 116). Yet, only two years later, OMB Directive No. 15 reclassified South Asians as "Asian” (Yanow 2002). 
Since the 1980 census, all respondents have been required to answer a question asking about race as well as the question about Hispanic origin. However, over 42 per cent of Hispanics chose the "some other race" option in response to the question on race in 2000 (Hitlin, Brown, and Elder 2007: 591). In 2010, the US Census Bureau added an instruction to the Hispanic origin question in the 2010 census - "For this census, Hispanic origins are not races"-in an attempt to remind the general public to consider race and Hispanic origin as separate concepts.

All three of the nations' censuses also relied at least some of the time in the 20th century on cultural attributes to measure race and ethnicity. In Australia, the 1984 Borrie Report deemed a selfperceived ethnicity question to be too subjective and thus inadequate in capturing an individual's "ethnic origins." Because the Australian census discontinued a racial origin question in 1976 and never included a direct ethnicity question, at least of the self-identification type, "ethnicity" has come to be measured through eight questions that reflect social attributes (such as non-English language spoken), cultural origins (such as birthplace of parents), and, more recently, ancestry. The difficulty in distinguishing between ethnicity, nationality, and origins is reflected in the Australian Bureau's periodic testing of "ethnicity" type questions in the 1980s and 1990s (ABS 1984, 1994).

The ancestry question was first intended to measure ethnic composition through the respondents' origins instead of their subjective perceptions of their ethnic background, and so the instructions for answering the question guided Australians towards considering their grandparents' generation as the benchmark for determining their origins:

'Ancestry' means the ethnic or national group from which you are descended. It is quite acceptable to base your answer on your grandparents' ancestry. Persons of mixed ancestry who do not identify with a single group should answer with their multiple ancestry. Persons who consider their ancestry to be Australian may answer 'Australian' (Kunz and Costello 2003: 7).

But respondents were still confused about the intent of the question, and the confusion was particularly pronounced among those whose families had been in Australia for many generations (Pink 2007). Thus, the ABS decided not to include the ancestry question after the 1986 census. When the question reappeared in 2001, the ABS stated that responses to this question should be paired with those to the question on birthplace of parents, in order to produce acceptable quality data (Edwards 2003: 61).

A tendency of enumerators and the general population to consider cultural attributes as the basis of ethnicity also occurred in Canada during the 20th century. In the Canadian mid-century censuses, the Dominion Bureau of Statistics explicitly warned enumerators:

Above all, do not assume that the answer given to Question 12 [which asked for first language spoken] establishes the answer to the question on origin (Dominion Bureau of Statistics, 1951 and 1961 instructions to the enumerators; clarification in parentheses added.)

In spite of the emphatic instructions, if a person refused or would not provide an answer to the question on origins, enumerators were then instructed to use the information provided on language spoken by the respondent to determine origins (if an immigrant), or (if Canadian-born) ancestor on the male side. After the switch to a mail-in/mail-out census in 1971, the questionnaire instructions continued to advise respondents to use the language they or their ancestors spoke on first coming to this continent as a guide to their ethnic origins. The instructions also advised the general Canadian public not to let language characteristics such as speaking "French" or "German" override a specific origin such as "Haitian" or "Austrian" (Statistics Canada 1976, 1983, 1991, 1996, 2001, 2006).

In sum, the statistical agencies in all three countries have had to deal with continuing problems distinguishing race, nationality or national descent, ethnicity, and cultural attributes. The difficulties 
of producing questions that are easy to answer and provide clear and consistent responses have been compounded by inconsistencies in how the statistical agencies understand the concepts that they are mandated to follow, ${ }^{3}$ and in how enumerators and the general populations understand them. In general, the solution seems to have been to add more questions and more instructions to the census schedules, in an effort to guide the general population on how to distinguish race, ethnicity, national origins, and cultural attributes, while simultaneously (at least in the cases of Australia and Canada), avoiding explicitly biological definitions of race.

\section{Complexities introduced by immigration and intermarriage}

All three countries experienced the in-migration of national groups new to the country, the growth of smaller or previously ignored racial and ethnic groups, and increasing numbers of respondents with multiple origins because of intermarriage. The first reaction to these social-demographic changes was to add more response categories to the census questions on race and ethnicity. Tables 2 through 4 present the changes in number and content of categories in the race and ethnicity questions in Australia, Canada, and the United States. The Canadian census of 1950 listed seventeen explicit options - fifteen European nationalities (such as English, French, Irish, and Scottish) plus "Native Indian" and "Jewish." In 1960, following the in-migration of refugees and displaced persons from Europe after WWII, eleven more categories—such as Austrian, Belgian, and Roumanian—were added (Table 3-a). Meanwhile, the changes to the response categories for the visible minority question have

Table 2. Mode, response options, and examples provided for the race and ethnicity questions in Australian censuses, 1950s-2010/11.

\begin{tabular}{|c|c|c|c|c|}
\hline & 1954 Race & 1961 Race & 1971 Race origin & 1976 Race origin \\
\hline $\begin{array}{l}\text { Mode } \\
\text { Options }\end{array}$ & Write-in & Write-in & $\begin{array}{l}\text { Checkbox plus write-in } \\
\text { European origin } \\
\text { Aboriginal origin } \\
\text { Torres Strait } \\
\text { Islander origin } \\
\text { Other origin } \\
\text { (state only one) } \\
\end{array}$ & $\begin{array}{l}\text { Checkbox plus write-in } \\
\text { European origin } \\
\text { Aboriginal origin } \\
\text { Torres Strait } \\
\text { Islander origin } \\
\text { Other origin } \\
\text { (state only one) } \\
\end{array}$ \\
\hline & 1986 Ancestry & 2001 Ancestry & 2006 Ancestry & 2011 Ancestry \\
\hline $\begin{array}{l}\text { Mode } \\
\text { Options }\end{array}$ & Write-in & $\begin{array}{l}\text { Checkbox plus write-in } \\
\text { English } \\
\text { Irish } \\
\text { Italian } \\
\text { German } \\
\text { Greek } \\
\text { Chinese } \\
\text { Australian } \\
\text { Other (write-in) }\end{array}$ & $\begin{array}{l}\text { Checkbox plus write-in } \\
\text { English } \\
\text { Irish } \\
\text { Italian } \\
\text { German } \\
\text { Scottish } \\
\text { Chinese } \\
\text { Australian } \\
\text { Other (write-in) }\end{array}$ & $\begin{array}{l}\text { Checkbox plus write-in } \\
\text { English } \\
\text { Irish } \\
\text { Scottish } \\
\text { Italian } \\
\text { German } \\
\text { Chinese } \\
\text { Australian } \\
\text { Other (write-in) }\end{array}$ \\
\hline Examples & $\begin{array}{l}\text { Greek, } \\
\text { English, Indian, } \\
\text { Armenian, } \\
\text { Aboriginal, } \\
\text { Chinese }\end{array}$ & $\begin{array}{l}\text { Other (write-in) } \\
\text { Vietnamese, } \\
\text { Hmong, Dutch, } \\
\text { Kurdish, Maori, } \\
\text { Lebanese, } \\
\text { Australian South Sea } \\
\quad \text { Islander }\end{array}$ & $\begin{array}{l}\text { Other (write-in) } \\
\text { Greek, Vietnamese, } \\
\text { Hmong, Dutch, } \\
\text { Kurdish, Maori, } \\
\text { Lebanese, } \\
\text { Australian South Sea } \\
\quad \text { Islander }\end{array}$ & $\begin{array}{l}\text { Other (write-in) } \\
\text { Greek, Vietnamese, } \\
\text { Hmong, Dutch, } \\
\text { Kurdish, Maori, } \\
\text { Lebanese, } \\
\text { Australian South Sea } \\
\text { Islander }\end{array}$ \\
\hline
\end{tabular}

3. In Australia, the ABS determines the nature of the questions to be included on national censuses; in Canada, it is the Treasury Board of Canada; and in the United States, it is the OMB. 
Table 3-a. Mode, response options, and examples provided for the origins question in Canadian censuses, 1951-2011.

\begin{tabular}{|c|c|c|c|c|c|}
\hline & $\begin{array}{c}1951 \\
\text { Origin }\end{array}$ & $\begin{array}{c}1961 \\
\text { Ethnic group }\end{array}$ & $\begin{array}{c}1971 \\
\text { Ethnic group }\end{array}$ & $\begin{array}{c}1981 \\
\text { Ethnic origins }\end{array}$ & $\begin{array}{c}1986 \\
\text { Ethnic group }\end{array}$ \\
\hline Mode & Checkbox & Checkbox & Checkbox & Checkbox & $\begin{array}{l}\text { Checkbox plus write- } \\
\text { in ( } 3 \text { blank lines) }\end{array}$ \\
\hline Options/ & English & Austrian & English & French & French \\
\hline \multirow[t]{30}{*}{ Examples } & French & Belgian & French & English & English \\
\hline & Irish & Czech & German & Irish & Irish \\
\hline & Netherlands & Danish & Irish & Scottish & Scottish \\
\hline & Scottish & English & Italian & German & German \\
\hline & Norwegian & Estonian & Jewish & Italian & Italian \\
\hline & Welsh \& Manx & French & Native Indian - & Ukrainian & Ukrainian \\
\hline & Polish & German & Band & Dutch & Dutch (Neth.) \\
\hline & Czech \& Slovak & Greek & Native Indian - & Polish & Chinese \\
\hline & Russian & Icelandic & Non-Band & Jewish & Jewish \\
\hline & Finnish & Irish & Netherlands & Chinese & Polish \\
\hline & Swedish & Italian & Norwegian & Native Peoples & Black \\
\hline & German & Jewish & Polish & (Inuit, Status or & Inuit \\
\hline & Ukrainian & Lithuanian & Scottish & registered Indian, & North Amer. Indian \\
\hline & Italian & Negro & Ukrainian & Non-status & Métis \\
\hline & Native Indian & Netherlands & Other - & Indian, Métis) & Other ethnic or \\
\hline & Jewish & Norwegian & write here & Other & cultural group(s) \\
\hline & Unknown & Polish & & & - (3 blank lines $)$ \\
\hline & If not listed, & Roumanian & & & \\
\hline & write below & Russian & & & \\
\hline & & Scottish & & & \\
\hline & & Slovak & & & \\
\hline & & Swedish & & & \\
\hline & & Ukrainian & & & \\
\hline & & Welsh & & & \\
\hline & & Yugoslavic & & & \\
\hline & & Native Indian - & & & \\
\hline & & Band member/ & & & \\
\hline & & Non-Band & & & \\
\hline & & If not listed, write & & & \\
\hline & & below & & & \\
\hline
\end{tabular}

been minimal. For example, there were eleven categories in 1996, and one of the categories-Arab/ West Asian-was separated into "Arab" and "West Asian" in the subsequent censuses (Table 3-b).

In the US Census, the list of responses to the race question was also lengthened over time. The 1950 census listed seven groups; by 1990, it listed fifteen (see Table 4). While the list maintains the original seven groups- "White," "Negro" [later changed to "Black, African American, or Negro"], "American Indian" (later changed to "American Indian or Alaska Native"], "Japanese," "Chinese," "Filipino," and "Other"), new additions mainly concerned the "Asian and Pacific Islander" population. The changes established access to entitlement programmes for officially recognized minority groups (Lee 1993: 80) as well as establishing proof of inclusion and acceptance in American society (Eisenberg and Kymlicka 2011).

In Australia, the race and racial origin questions were meant to distinguish "White," "European," or "British," on the one hand, from the "coloured" population, on the other (Horn 1987). Thus, the options for the race/racial origin question were not extensive (Table 2). Meanwhile, the ancestry question was introduced to collect information on newcomers from non-traditional countries. In an ABS Information Paper, Pink (2007: 38) states: 
Table 3-a (continued).

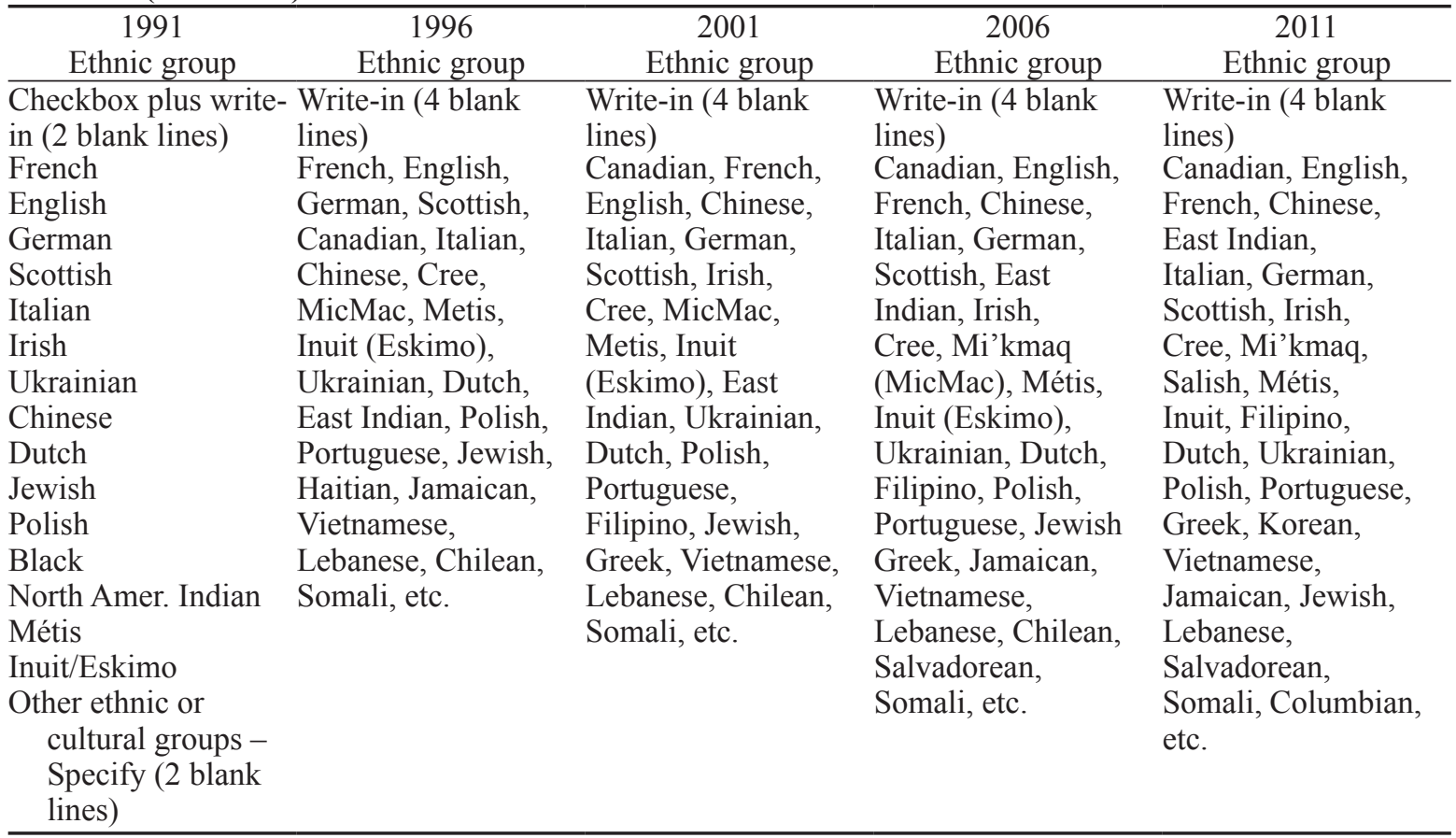

Table 3-b. Mode, response options, and example categories of 'visible minority' in the Canadian census, 1950s-2010/11.

\begin{tabular}{|c|c|c|c|c|}
\hline \multirow{2}{*}{$\overline{\text { Mode }}$} & $\begin{array}{c}1996 \\
\text { Visible minority }\end{array}$ & $\begin{array}{c}2001 \\
\text { Visible minority }\end{array}$ & $\begin{array}{c}2006 \\
\text { Visible minority }\end{array}$ & $\begin{array}{c}2011 \\
\text { Visible minority }\end{array}$ \\
\hline & $\begin{array}{l}\text { Checkbox plus write-in } \\
\text { ( } 1 \text { blank space) }\end{array}$ & $\begin{array}{l}\text { Checkbox plus write-in } \\
\text { ( } 1 \text { blank space) }\end{array}$ & $\begin{array}{l}\text { Checkbox plus write-in } \\
\text { (1 blank space) }\end{array}$ & $\begin{array}{l}\text { Checkbox plus write-in } \\
\text { (1 blank space) }\end{array}$ \\
\hline Options \& & White & White & White & White \\
\hline \multirow[t]{22}{*}{ Examples } & Chinese & Chinese & Chinese & South Asian (e.g., \\
\hline & South Asian (e.g., & South Asian (e.g., & South Asian (e.g., & East Indian, \\
\hline & East Indian, & East Indian, & East Indian, & Pakistani, Sri \\
\hline & Pakistani, Punjabi, & Pakistani, Punjabi, & Pakistani, Sri & Lankan, etc.) \\
\hline & Sri Lankan) & Sri Lankan, etc.) & Lankan, etc.) & Chinese \\
\hline & Black (e.g., African, & Black & Black & Black \\
\hline & Haitian, Jamaican, & Filipino & Filipino & Filipino \\
\hline & Somali) & Latin American & Latin American & Latin American \\
\hline & Arab/West Asian & Southeast Asian & Southeast Asian & Arab \\
\hline & (e.g., Armenian, & (e.g., Cambodian, & (e.g., Vietnamese, & Southeast Asian \\
\hline & Egyptian, Iranian, & Indonesian, & Cambodian, & (e.g., Vietnamese, \\
\hline & Lebanese, & Laotian, & Malaysian, & Cambodian, \\
\hline & Moroccan) & Vietnamese, etc.) & Laotian, etc.) & Malaysian, \\
\hline & Filipino & Arab & Arab & Laotian, etc.) \\
\hline & Southeast Asian & West Asian (e.g., & West Asian (e.g. & West Asian (e.g. \\
\hline & $\begin{array}{l}\text { (e.g., Cambodian, } \\
\text { Indonesian, }\end{array}$ & $\begin{array}{l}\text { Afghan, Iranian, } \\
\text { etc.) }\end{array}$ & $\begin{array}{l}\text { Iranian, Afghan, } \\
\text { etc.) }\end{array}$ & $\begin{array}{l}\text { Iranian, Afghan, } \\
\text { etc.) }\end{array}$ \\
\hline & Laotian, & Japanese & Korean & Korean \\
\hline & Vietnamese) & Korean & Japanese & Japanese \\
\hline & Latin American & Other - Specify & Other - Specify & Other - Specify \\
\hline & Japanese & & & \\
\hline & Korean & & & \\
\hline & Other - Specify & & & \\
\hline
\end{tabular}


Table 4. Mode, response options, and example categories for the race questions in US censuses, 1950-2010.

\begin{tabular}{|c|c|c|c|c|c|c|c|}
\hline & 1950 & 1960 & 1970 & 1980 & 1990 & 2000 & 2010 \\
\hline Mode & $\begin{array}{l}\text { Checkbox } \\
\text { plus write-in }\end{array}$ & $\begin{array}{l}\text { Checkbox } \\
\text { plus write-in }\end{array}$ & $\begin{array}{l}\text { Checkbox plus } \\
\text { write-in }\end{array}$ & $\begin{array}{l}\text { Checkbox plus } \\
\text { write-in }\end{array}$ & $\begin{array}{l}\text { Checkbox plus } \\
\text { write-in }\end{array}$ & $\begin{array}{l}\text { Checkbox } \\
\text { plus write-in }\end{array}$ & $\begin{array}{l}\text { Checkbox plus } \\
\text { write-in }\end{array}$ \\
\hline Options/ & White & White & White & White & White & White & White \\
\hline Examples & $\begin{array}{l}\text { Negro } \\
\text { American } \\
\quad \text { Indian } \\
\text { Japanese } \\
\text { Chinese } \\
\text { Filipino } \\
\text { Other race - } \\
\quad \text { spell out }\end{array}$ & $\begin{array}{l}\text { Negro } \\
\text { American } \\
\quad \text { Indian } \\
\text { Japanese } \\
\text { Chinese } \\
\text { Filipino } \\
\text { Hawaiian } \\
\text { Part Hawaiian } \\
\text { Aleut } \\
\text { Eskimo } \\
\text { Other (etc.) }\end{array}$ & $\begin{array}{l}\text { Negro or } \\
\quad \text { Black } \\
\text { Indian (Amer.) } \\
\quad \text { (print tribe) } \\
\text { Japanese } \\
\text { Chinese } \\
\text { Filipino } \\
\text { IHawaiian } \\
\text { Korean } \\
\text { Other (print } \\
\text { race) }\end{array}$ & $\begin{array}{l}\text { Black or } \\
\text { Negro } \\
\text { Japanese } \\
\text { Chinese } \\
\text { Filipino } \\
\text { Korean } \\
\text { Vietnamese } \\
\text { Indian (Amer.) } \\
\text { (print tribe) } \\
\text { Asian Indian } \\
\text { Hawaiian } \\
\text { Guamanian } \\
\text { Samoan } \\
\text { Eskimo } \\
\text { Aleut } \\
\text { Other } \\
\text { (specify) }\end{array}$ & $\begin{array}{l}\text { Black or } \\
\text { Negro } \\
\text { Indian (Amer.) } \\
\text { (print the } \\
\text { name of the } \\
\text { enrolled or } \\
\text { principal } \\
\text { tribe.) } \\
\text { Eskimo } \\
\text { Aleut } \\
\text { Chinese } \\
\text { Filipino } \\
\text { Hawaiian } \\
\text { Korean } \\
\text { Vietnamese } \\
\text { Japanese } \\
\text { Asian Indian } \\
\text { Samoan } \\
\text { Guamanian } \\
\text { Other API } \\
\text { Other race } \\
\text { (print race) }\end{array}$ & $\begin{array}{l}\text { Black, } \\
\text { African } \\
\text { Am., or } \\
\text { Negro } \\
\text { American } \\
\text { Indian or } \\
\text { Alaska } \\
\text { Native } \\
\text { (print the } \\
\text { name of the } \\
\text { enrolled or } \\
\text { principal } \\
\text { tribe.) } \\
\text { Asian Indian } \\
\text { Chinese } \\
\text { Filipino } \\
\text { Japanese } \\
\text { Korean } \\
\text { Vietnamese } \\
\text { Other Asian } \\
\text { (print race) } \\
\text { Native } \\
\text { Hawaiian } \\
\text { Guamanian or } \\
\text { Chamorro } \\
\text { Samoan } \\
\text { Other Pacific } \\
\text { Islander } \\
\text { (print race) } \\
\text { Some other } \\
\text { race (print } \\
\text { race) }\end{array}$ & $\begin{array}{l}\text { Black, African } \\
\text { Am., or Negro } \\
\text { American } \\
\text { Indian or } \\
\text { Alaska Native } \\
\text { (print the name } \\
\text { of the enrolled } \\
\text { or principal } \\
\text { tribe.) } \\
\text { Asian Indian } \\
\text { Chinese } \\
\text { Filipino } \\
\text { Japanese } \\
\text { Korean } \\
\text { Vietnamese } \\
\text { Other Asian } \\
\text { (print race) } \\
\text { Native Hawaiian } \\
\text { Guamanian or } \\
\text { Chamorro } \\
\text { Samoan } \\
\text { Other } \\
\text { PacificIslander } \\
\text { (Print race) } \\
\text { Some other race } \\
\text { (print race) } \\
\text { Other Asian - } \\
\text { Print race, } \\
\text { for example, } \\
\text { Hmong, } \\
\text { Laotian, Thai, } \\
\text { Pakistani, } \\
\text { Cambodian, } \\
\text { and so on. } \\
\text { Other Pacific } \\
\text { Islander - } \\
\text { print race, } \\
\text { for example, } \\
\text { Fijian, Tongan, } \\
\text { and so on. }\end{array}$ \\
\hline
\end{tabular}

A person's ancestry, in conjunction with their countries of birth and information on whether their parents were born in Australia or overseas, provides a good indication of the ethnic background of first and second generation Australians. This data is used to inform delivery of services to particular ethnic communities.

Thus, the ABS responded to the introduction of new groups through immigration not by adding categories, but instead by adding questions on ethnicity and developing a classification scheme that incorporates ancestry and place of birth of the respondent, and of the respondent's mother and father. This rationale in Australia contrasts with the rationale for adding the ancestry question in the US 


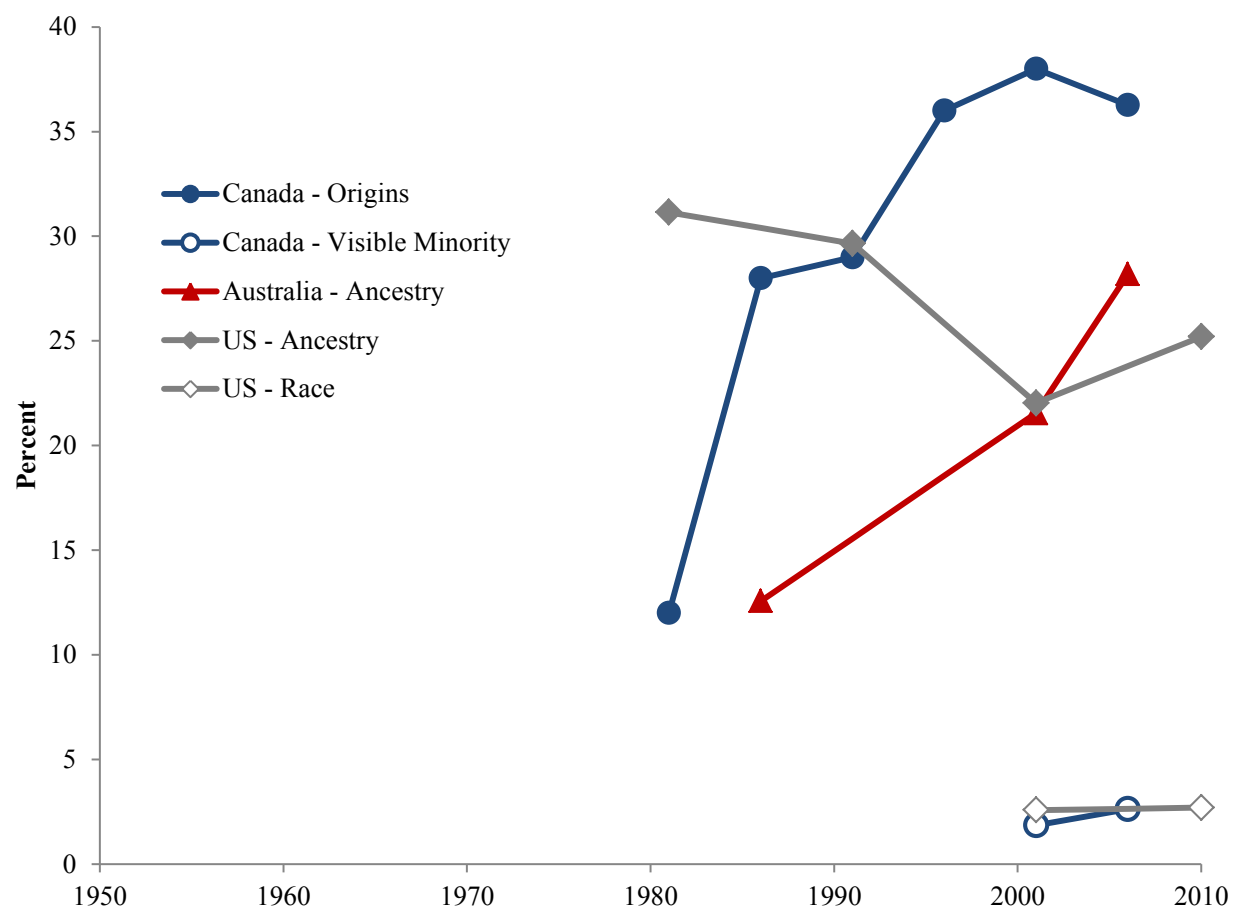

Fig. 1. Percentages of people providing multiple responses to the origin, visible minority, and ancestry questions on Australian, Canadian, and US censuses. Note: The last data point for ancestry in the US is based on data from the 2010 American Community Survey.

censuses. In the US, the ancestry question was meant to ensure that native-born Americans who were the descendants of European immigrants entering during the 19th and early 20th century would be identified in descriptions of the race and ethnic composition of America (Perez and Hirschman 2009).

A more telling demographic source of complexity in the measurement of racial and ethnic origins is intermarriage. In all three nations, intermarriage between the major racial groups, and especially among the European ethnic or origin groups, occurred and became more frequent by the end of the 20th century. Intermarriage both blurs and accelerates the blurring of the boundaries between groups, whether defined through origins/ancestry, cultural origins, or identity, because the children of mixed marriages may claim membership in or identify with one or both groups.

Before 1981, Canadian censuses partially sidestepped the issue by asking respondents to trace their origins only through male ancestors. The United States vacillated: in 1970, the father's race was used for persons of mixed race who could not provide a single response but in 1980 the mother's race was used. Australia was very forthright: from 1954 through 1966, "half-caste" Australians were instructed to give particulars, e.g., 1/2 Aboriginal, 1/2 Chinese. In 1971 and 1976, Australia attempted to pull back on this awkward categorization by shifting to self-identification as the basis for the categorizing of persons of mixed race: "If of mixed [race] origin, indicate the one to which he considers himself to belong. Tick one box only or give one origin only." Because Australia dropped the racial origin question after 1976, the issue of mixed race (although not mixed ancestry) disappeared from view.

One response to the complexity of multiple origins is to provide the general public with the opportunity to select multiple responses, so that the nation's residents may identify themselves as they see fit. But the three countries took slightly different approaches. In the 1981 Canadian census, a write-in space was added to the question, thus implicitly allowing Canadians to report two origins. Then, from 
1986 on, the Canadian censuses explicitly told respondents to indicate as many responses as were applicable, and individuals could include even more, by writing in paired responses (such as "CanadianUkrainian") on one of the lines, with up to six different categories being recorded. Respondents were also given the option of selecting more than one category on the visible minority question.

In the US, respondents have been allowed to write in more than one ancestry or ethnic origin on the ancestry question, which appeared on the long forms of the censuses between 1980 and 2000, and on the American Community Survey after the 2000 census. Many chose to provide multiple answers, most often involving at least one European ancestry (Brittingham and de la Cruz 2004). In 2000 and 2010, Americans were also instructed to "mark all that apply" in response to the question on race, and so could choose up to five different responses. In 2001, Australia followed the footsteps of the US and of Canada, and allowed its residents to list more than one ancestry "if necessary."

Figure 1 shows the upward swings in the percentages of Australians, Canadians, and Americans providing multiple responses to questions on origins or ancestry, starting in the 1980s-although the general upward trend in the United States was interrupted by a decline between the 1990 and 2000 censuses. The startling jump between 1981 and 1986 in the percentage of Canadians providing multiple responses to the "origins" question is probably a result of the instructions accompanying the question in 1986, which explicitly invited multiple responses. In addition, Figure 1 also shows the small but noticeable rise in the percentage of Canadians declaring that they were members of more than one visible minority group from the late 1990s on. Similarly, a small percentage of Americans chose more than one race group from 2000 on, although rates of multi-racial reporting vary substantially across racial groups, and are particularly low among black respondents (Lee and Bean 2007; Tafoya et al. 2005).

Allowing multiple responses to the origins/race/ancestry questions means that the results are not easily comparable to the results obtained in earlier censuses. Moreover, even simple tabulations based on cross-sectional data become difficult to design and unwieldy to publish. For example, allowing multiple responses to a question with even only five major race categories yields over 30 possible combinations, and many more if ordering of the responses is taken into account.

Bridging methods have been developed to allocate a single race for those who identify with multiple races. Liebler and Halpern-Manners (2008: 158) argue that this approach allows analysts to "make relatively accurate cross-time comparisons by retaining historically consistent and substantively meaningful groupings of people." However, these techniques are inevitably based on assumptions about what race respondents would pick if forced to choose, and of course, absorbing multiple responses into single-response categories erases the information provided by respondents' arrays of choices.

The increased numbers and types of questions tapping race and ethnicity in the censuses of the three countries has thus been attended by a growth in the number of categories and options for answering the questions. In general, the number of available options or categories not only has increased over time for the questions in all three countries, it is now possible for the general public to provide multiple responses to the questions on race and ethnic ancestry. The number of possible outcomes to the questions has thus grown dramatically in each of the three nations.

\section{Generational aging and the rise of nominal categories}

Over the course of the 20th century, the proportion of third- and later-generation Australians, Canadians, and Americans in their respective countries' populations rose, and the salience of their European origins faded. ${ }^{4}$ Moreover, the notion of European national groups, such as Italian versus

4. This phenomenon is also present in New Zealand, where the number of people claiming "New Zealander" as their ethnic group increased five-fold between the 2001 and 2006 censuses (Kukatai and Didham 2009, 2012). 
Stevens et al:: Measuring race and ethnicity in the censuses of Australia, Canada, and the United States

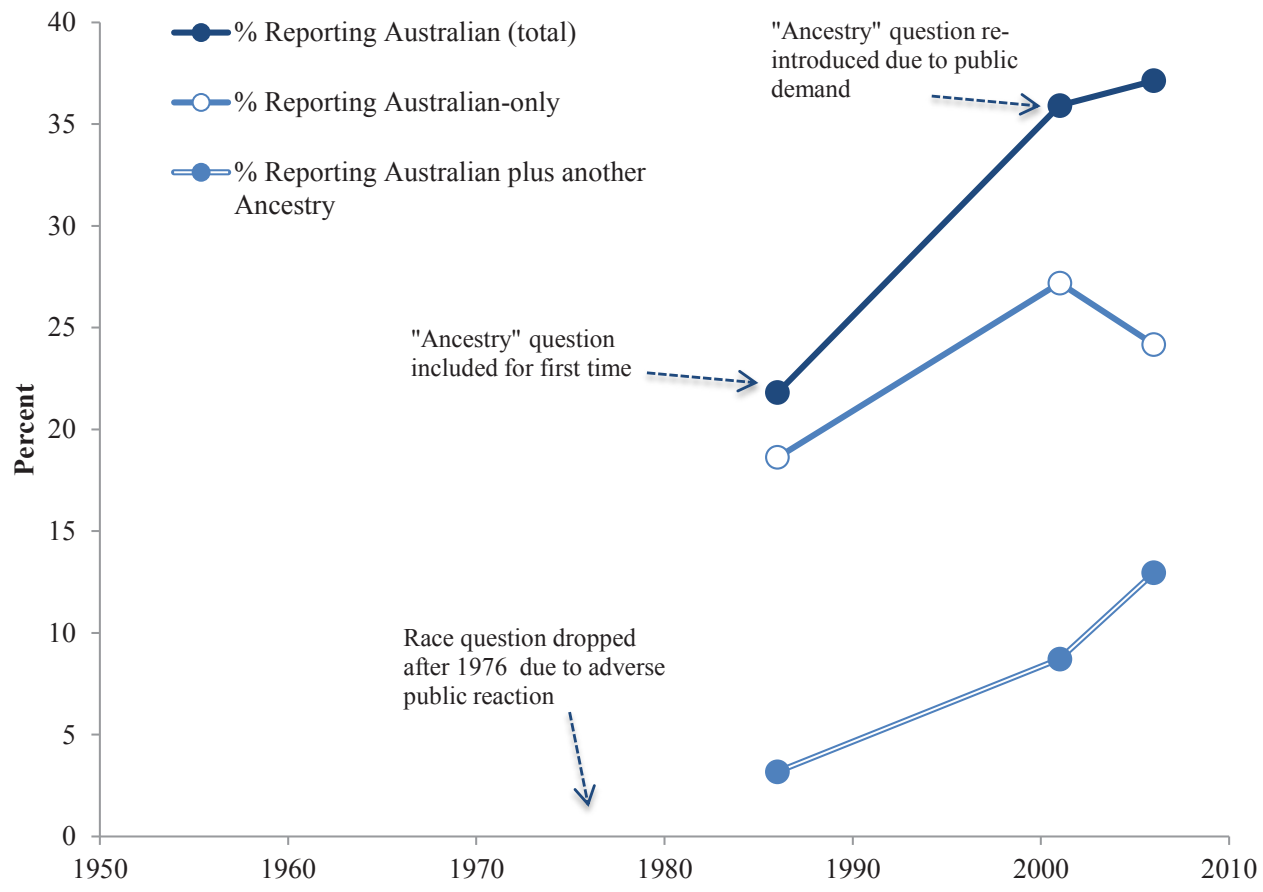

Fig. 2-a. Percentages of people reporting their ancestries as "Australia" or "Australian" plus another category on Australian censuses, 1986-2006.

German, constituting separate racial and ethnic groups had largely withered away. These demographic processes set the stage for residents of Australia, Canada, and the United States to identify their origins and ancestry as being rooted in their country of residence. As Kukutai and Didham (2009) argue, the rise of the nominal category was not simply a rejection of ethnic labelling but a reaction by multi-generational members of the dominant group to the politicization of the rights of indigenous people and the increasing ethnic diversity resulting from immigration.

Australians were allowed to identify their ancestry as "Australian" in 1986, and about 20 per cent did so. The ancestry question reappeared on the census schedule in 2001, when "Australian" was included as a checkbox. The ABS (2005: 7-8) gave two reasons why it was included:

Firstly, many people consider that since European inhabitation of the land and the associated conception of the term 'Australian', an identifiable and acknowledged 'Australian' culture has developed in this country. Secondly, an Australian category is needed to make the classification practical, useful and feasible for collecting, classifying and disseminating statistics on ancestry, ethnicity or cultural diversity as many people will indicate that their ancestry, etc. is 'Australian'.

The offering of "Australian" in the 2001 census as a possible response resulted in a large jump in the percentage, from 22 to 36 per cent, of people declaring themselves to be Australian (See Figure 2a).

In 1951 and 1961, some Canadian residents refused to select any of the categories provided on the "Origin" question on the Canadian census schedule, or did not know how to answer the question on "ethnic or cultural group." If the person insisted - the word was italicized in the 1951 instructions to enumerators - that his ethnic or cultural group was "Canadian" or "U.S.A." or "American" then the enumerator was told to comply and to enter the reply in the write-in space (Dominion Bureau of Statistics 1951, 1961: 34), although the percentages of people writing in "Canadian" were not published. In 1986, when Canadians were allowed (although not prompted) to write in "Canadian," less than 1 per cent of the population did so. But in 1991, over 4 per cent wrote in "Canadian," possibly in reaction to the "Count Me Canadian" campaign (see Figure 2-b). 
Before the 1991 census was fielded, Statistics Canada had decided to use a frequency of 3 per cent as a trigger for including a specific suggestion in the origins question on the following census. Because 4 per cent of the respondents in the 1991 census wrote in "Canadian," the origins question in the 1996 census included "Canadian" as a suggested response. It was the fifth listed example (after French, English, German, and Scottish) and happened to begin the second line of examples. It was thus, as Boyd (1999) noted, in an eye-catching position. The outcome was dramatic, with almost 20 per cent of the population choosing the term "Canadian" in $1996^{5}$ to describe their ethnic origins. Moreover, because the 1996 census question on origins allowed multiple responses, another 12 per cent chose to describe their origins as "Canadian" plus some other term, e.g., 'Greek-Canadian'. Overall, almost a third of respondents described themselves as Canadian at least in part, and the decades of Statistics Canada imploring the general population to distinguish between nationality and ethnic origins were undone in one fell swoop. ${ }^{6}$ In a display of nationalism or perhaps, for some respondents, a claiming of membership in Canadian society (Lee and Edmonston 2010), the appeal of being able to choose "Canadian" as a single or multiple response continued to strengthen. Five years later, in the 2001 census when "Canadian" was the first listed example, over 40 per cent of the population described themselves as Canadian. In the 2006 census (and the 2011 National Household Survey), the proportion of respondents choosing the option of "Canadian" in response to the question on ethnic origins fell back to about a third

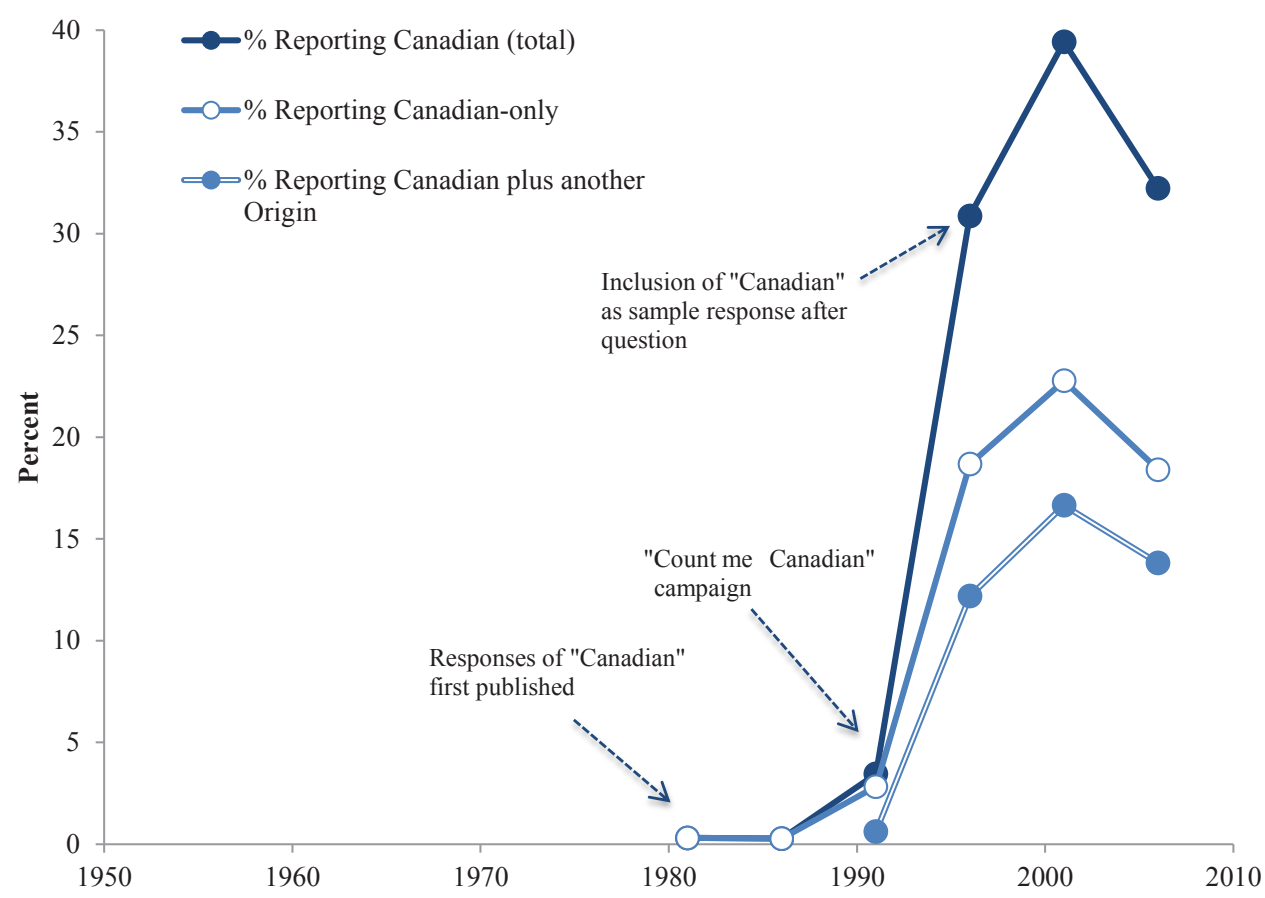

Fig. 2-b. Percentages of people reporting their origins as "Canadian" or "Canadian" plus another category on Canadian censuses, 1981-2006.

5. See Boyd et al. (2000), Boyd and Norris (2001), and Lee and Edmonston (2010) for detailed discussions of who reported "Canadian."

6. Thomas (2005) argues that the shift towards "Canadian" between the 1991 and 1996 censuses was the result of an emotional reaction to the debate over free trade in 1991. It seems unlikely, however, that this alone could have propelled over a third of the general Canadian population to reconsider their origins. 
Stevens et al:: Measuring race and ethnicity in the censuses of Australia, Canada, and the United States

(Statistics Canada 2008, 2013). The decline after 2001 may have occurred because the statement "Ancestor is usually more distant than a grandparent" accompanied the question on ancestry. ${ }^{7}$ Still, the evidence is solid that Pryor et al.'s (1992) prediction was correct: "Canadian" origin has entered the lexicon of the Canadian ethnic mosaic.

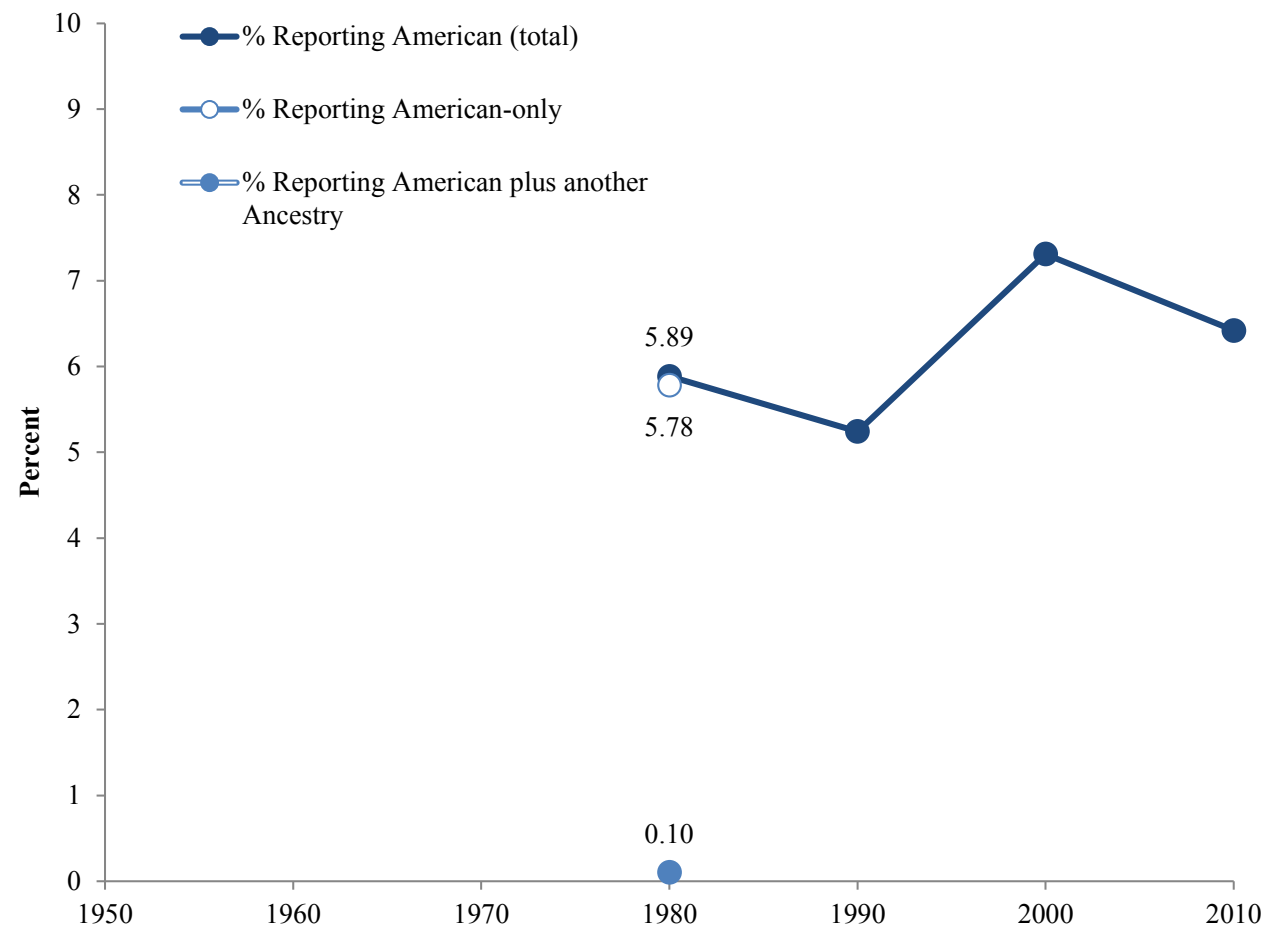

Fig. 2-c. Percentages of people reporting their ancestries as "American" in the US censuses, 1980-2000 and the 2010 American Community Survey.

Figure 2-c suggests that people in the United States did not seize the opportunity to identify themselves to the same extent as their counterparts in Australia and Canada. Still, the category of "American only" experienced the largest numerical growth among all categories between 1990 and 2000 (Brittingham and de la Cruz 2004). The percentage of those who reported as "American only" increased from 5 percent in 1990 to 7 percent in 2000. The zero percentage for the category of "American plus another ancestry" from 1990 on is attributable to the US Census Bureau's decision not to tabulate most of the multiple ancestry responses that involve "American" (Brittingham and de la Cruz 2004; US Census Bureau 1992). Instead, dual responses such as "Italian American" are recoded and tabulated under the single ancestry response "Italian." Thus, the published data only inform us about the number of "American only" responses-although there are a few exceptions: the multiple-ancestry responses "American Indian," "Mexican American," and "African American" are recorded because the US Census Bureau considers these groups as "different from those who reported as 'Indian', 'Mexican', or 'African", respectively (US Census Bureau 1992: B-1).

7. Note the difference between Australia and Canada: Canada is directing respondents to think of ancestors before their grandparents, while Australia is guiding their respondents to focus on their grandparents. 


\section{Summary and conclusions}

Australia, Canada, and the United States have used their censuses as a source of information about the ethnic and racial composition of their populations. Although the recent censuses of the three countries employ different questions, which tap into varying conceptualizations of race and ethnicity, each of the censuses has had to deal with common problems in the measurement of race and ethnicity.

The first of these shared problems concerns the ambiguities and confusion, found among the personnel of the census offices as well as their nations' residents, surrounding the concepts of race and ethnicity. These are complex, socially volatile, and situationally specific concepts, and so not surprisingly, it has proven impossible to derive a stable, clear, and defensible set of questions and responses. Instead, the census offices of the three countries have constantly tinkered with the race and ethnicity questions, sometimes changing the wording of the questions, revising the concepts underlying the questions, adding and deleting specific response categories, and adding more questions-all in an attempt to clarify or to triangulate the race and ethnic characteristics of the nation's residents. The result is an ever-changing set of questions and categories, some of which have temporarily lost authority. Notable among these constructed concepts are the putatively ethnic category "Hispanic" in the United States and the racially based concept of "visible minority" in Canada.

The second of the shared problems encountered by the three countries in the measurement of race and ethnicity concerns the complexities introduced by intermarriage, magnified by the shift towards emphasizing racial and ethnic identity rather than a biologically based operationalization. The three countries chose a similar solution: allowing respondents to provide multiple responses. This procedure results in a departure from the major statistical property of exclusivity, damage to data comparability across time within each nation's series of censuses, and problems describing the racial and ethnic composition of the population at any given time without having to resort to arbitrary rules about how to weight or present each of the categories appearing in multi-partite responses. Such a shift in survey methodology also increases the risk of splintering racial and ethnic categories and the ascension of identity politics (Robbin 2000). As Thompson (2012) points out, allowing such a wide array of options personalizes the census and leads to demands that individuals and subgroups "see" themselves in the census. There are now numerous examples in both the scholarly literature (e.g., Yanow 2002) and in the public press (e.g., Carlson 2010) that present and lament the fact that a specific combination of origins or racial identities, e.g., Armenian-Irish, is not listed on the census schedule or published separately in census tabulations.

Paradoxically, even as allowing multiple responses to census questions asking about ethnic or racial identities has led to a wealth of unique combinations, at least one response option-the declaration of a national allegiance or citizenship such as "Australian," "Canadian," or "American"—-seems to be gaining ground in all three countries. In addition, the concept of 'bi-racial' or 'multi-racial' per se as an explicit response, although devoid of any cultural, national or ancestral content and harking back to an essentialist view of racial groupings (Nobles 2011), also seems to be gaining some support in Canada and the US (e.g., Aspinall 2003).

Finally, one of the most interesting problems shared by the three countries concerns the behaviour of the population. Scholars often assume that individuals responding to a national census have little agency in the design and production of census data; respondents are often considered to be passive, responding only when asked, to the census queries designed and presented by their respective national census offices. Yet it is clear that Australians, Canadians, and Americans have often refused to go along with their censuses' approaches to the measurement of their racial and ethnic character- 
Stevens et al.: Measuring race and ethnicity in the censuses of Australia, Canada, and the United States

istics. Over the course of the 20th century, Australians and Canadians, in particular, have pushed their respective census offices to recognize that "Australian" and "Canadian," respectively, are appropriate responses to questions on origins or ancestry. In the American case, in spite of the insistence by the US Census Bureau that the "Hispanic origin" question refers to ethnicity rather than to race, over 40 per cent of Americans who identify themselves as Hispanic then sidestep declaring any specific race. This refusal to select one of the provided racially specific responses could be construed as an implicit statement that "Hispanic" constitutes a racial group. ${ }^{8}$ It is also clear that the general population often takes the countries' respective statistical offices unawares. The alacrity with which Australians and Canadians have seized the option to define their ancestry through their nationality or citizenship, and the extent to which Hispanics in the United States have refused to identify their race using the offered categories, are changing the nature of the countries' statistics on race and ancestry.

These three countries, which share a common language and some commonalities in the demographic backgrounds of their populations, have grappled with these problems of measuring race and ethnicity in their national censuses in a variety of ways over the last half-century. None of the three seem to have landed upon a compelling solution. The sometimes large impact of minor shifts in question wording, in instructions, and in the listed examples of responses points to the significant role that arbitrary methodological details can play in producing a portrait of the racial and ethnic characteristics of a national population.

One suggested solution-the inclusion of more questions designed to capture the numerous dimensions of race and ethnicity (Burton et al. 2010)— quickly runs up against the limits of space on national census schedules, and would also result in data of marginal utility in empirical studies. Another possible solution is to gather "open-response data," in which respondents provide their own description of their race and ethnic characteristics (Aspinall 2012; Prewitt 2005, 2010). Such data might yield enough detail to describe a "super-diverse" population, but the data would be expensive to code, difficult to tabulate and present, and probably difficult to compare across time or region. The best approach may well be to concede that race and ethnicity are complex and dynamic concepts that shift over time and across circumstances, and that the measurement of racial and ethnic characteristics of a nation's population should reflect this accordingly. Thus, data analysts and public officials might be better off de-emphasizing the methodological ideals of replicability and comparability of census data across time in favour of emphasizing the racial and ethnic distinctions that the nations and their populations find important.

\section{References}

ABS (Australian Bureau of Statistics). 1984. The Measurement of Ethnicity in the Australian Census of Population and Housing: Report to the Australian Statistician by the 1986 Population Census Ethnicity Committee. Canberra: Australian Bureau of Statistics.

1994. Testing of Ethnic Origin Questions for the 1996 Census. Canberra: Australian Bureau of Statistics.

2002. Form Design Testing. Canberra: Australian Bureau of Statistics.

8. The U.S. Census Bureau incorporated a set of experiments in the 2010 U.S. Census to investigate how best to ask about race and ethnicity. In the final report describing the results of the experiments, Compton et al. (2013) recommend combining the two questions asking about Hispanic ethnicity and race, because this approach would lower the non-response rate among Hispanics. 
2005. Australian Standard Classification of Cultural and Ethnic Groups. ASCCEG. Canberra: Australian Bureau of Statistics.

Aspinall, P.J. 2003. The conceptualization and categorization of mixed race/ethnicity in Britain and North America: Identity options and the role of the state. International Journal of Intercultural Relations 27(3):269-296.

2012. Answer formats in British census and survey ethnicity questions: Does one response better capture 'superdiversity'? Sociology 46(2):354-364.

Boyd, M. 1999. Canadian, eh? Ethnic origin shifts in the Canadian census. Canadian Ethnic Studies 31:1-19.

Boyd, M., G. Goldmann, and P. White. 2000. Race in the Canadian census. In Visible Minorities in Canada, edited by L. Driedger and S. Halli. Montreal and Toronto: McGill, Queens, and Carleton University Press, p. 33-54

Boyd, M. and D. Norris. 2001. Who are the 'Canadians'? Changing census responses 1986-1996. Canadian Ethnic Studies 33:1-24.

Brittingham, A. and G.P. de la Cruz. 2004. Ancestry: 2000. Census 2000 Brief. Washington: US Census Bureau.

Burton, J., A. Nandi, and L. Platt. 2010. Measuring ethnicity: Challenges and opportunities for survey research. Ethnic and Racial Studies 33(8):1332-1349.

Carlson, P. 2010. America, One Door at a Time. The Washington Post. Retrieved on December 1, 2010 at www.washingtonpost.com.

Compton, E., M. Bentley, S. Ennis, and S. Rastogi. 2013. 2010 Census Race and Hispanic Origin Alternative Questionnaire Experiment. Washington: US Census Bureau.

Department of Justice (Canada). 1995. Employment Equity Act. S.C. 1995, c. 44. Ministry of Justice. Available online: http://laws.justice.gc.ca/PDF/Statute/E/E-5.401.pdf

Dominion Bureau of Statistics. 1951. Ninth Census of Canada, 1951: Form 2 Population. Ottawa: Dominion Bureau of Statistics.

1961. 1961 Census of Canada Enumeration Manual. Ottawa: Dominion Bureau of Statistics.

Edwards, R.W. 2003. ABS Views on Content and Procedures. Information Paper 2007.0. Canberra: Australian Bureau of Statistics.

Eisenberg, A., and W. Kymlicka. 2011. Bringing institutions back in: how public institutions assess identity. In Identity Politics in the Public Realm, edited by A. Eisenberg and W. Kymlicka. Vancouver: UBC Press. p. 1-30.

Evans, J., D. Kahles, and C. Bate. 1993. 1991 Census Data Quality: Aboriginal and Torres Strait Islander Counts. Canberra: Australian Bureau of Statistics.

Hattam, V. 2007. In the Shadow of Race: Jews, Latinos, and Immigrant Politics in the United States. Chicago: University of Chicago Press.

Hitlin, S., J.S. Brown, and G.H. Elder, Jr. 2007. Measuring Latinos: Racial vs. ethnic classification and self-understandings. Social Forces 86:587-611.

Horn, R.V. 1987. Ethnic origin in the Australian census. Journal of the Australian Population Association $4: 1-12$. 
Stevens et al:: Measuring race and ethnicity in the censuses of Australia, Canada, and the United States

Kertzer, D.I., and D. Arel. 2002. Censuses, identity formation and the struggle for political power. In Census and Identity: The Politics of Race, Ethnicity and Language in National Censuses, edited by D.I. Kertzer and D. Arel. Cambridge MA: Cambridge University Press. p. 1-39.

Khoo, S.-E., and D. Lucas. 2004. Australian Ancestries: 2001. Canberra: Australian Bureau of Statistics.

Kunz, C. 2003. 2001 Census: Ancestry - First and Second Generation Australians. Canberra: Australian Bureau of Statistics.

Kunz, C., and L. Costello. 2003. 2001 Census: Ancestry - Detailed Paper. Canberra: Australian Bureau of Statistics.

Kukutai, T., and R. Didham. 2009. In search of ethnic New Zealanders: National naming in the 2006 Census. Social Policy Journal of New Zealand 36:46-62.

- 2012. Re-making the majority? Ethnic New Zealanders in the 2006 census. Ethnic and Racial Studies 35(8):1427-1426.

Lee, J., and F.D. Bean. 2007. Reinventing the color line: Immigration and American's new racial/ethnic divide. Social Forces 86(2):561-586.

Lee, S.M. 1993. Racial classifications in the US Census: 1890-1990. Ethnic and Racial Studies 16:75-94.

Lee, S.M., and B. Edmonston. 2010. "Canadian" as national ethnic origin: Trends and implications. Canadian Ethnic Studies/Etudes ethniques au Canada 1:77-108.

Liebler, C.A., and A. Halpern-Manners. 2008. A practical approach to using multiple-race response data: A bridging method for public-use microdata. Demography 45:143-155.

Morning, A. 2008. Ethnic classification in global perspective: A cross-national survey of the 2000 census round. Population Research and Policy Review 27:239-272.

- 2009. Toward a sociology of racial conceptualization. Social Forces 87(3):1167-1192.

2011. The Nature of Race: How Scientists Think and Teach About Human Difference. Berkeley: University of California Press.

Nobles, M. 2011. The challenge of census categorization in the post-civil rights era. In Identity Politics in the Public Realm: Bringing Institutions Back In, edited by A. Eisenberg and W. Kymlicka. Vancouver: University of British Columbia Press. p. 31-50.

OMB (Office of Management and Budget). 1977. Directive No. 15: Race and Ethnic Standards for Federal Statistics and Administrative Reporting. Washington: Office of Management and Budget.

- 1997. Revisions to the standards for the classification of data on race and ethnicity. Federal Register 62(210):58781-58790.

Perez, A.D., and C. Hirschman. 2009. The changing racial and ethnic composition of the US population: Emerging American identities. Population and Development Review 35:1-51.

Pink, B. 2007. Census of Population and Housing: ABS Views on Content and Procedures. Canberra: Australian Bureau of Statistics.

Prewitt, K. 2005. Racial classification in America: Where do we go from here? Daedalus 134:5-17. - 2010. How to fix Census' broken race question. US A Today. Available online at http:/ / usatoday30.usatoday.com/news/opinion/forum/2010-07-13-column13_ST_N.htm. 
Pryor, E.T., G.J. Goldman, M.J. Sheridan, and P.M. White. 1992. Measuring ethnicity: Is 'Canadian' an evolving indigenous category? Ethnic and Racial Studies 15(2):214-235.

Robbin, A. 2000. Classifying racial and ethnic group data in the United States: The politics of negotiation and accommodation. Journal of Government Information 27(2):139-156.

Snipp, C.M. 2003. Racial measurement in the American census: Past practices and implications for the future. Annual Review of Sociology 29:563-588.

Statistics Canada. 1976. 1971 Census of Canada: Population. Introduction, Vol. 1: Part 5. Ottawa: Statistics Canada.

-1983. Summary Guide Total Population: 1981 Census of Population. Ottawa: Statistics Canada.

—. 1991. 1991 Census Guide and Reasons Why Questions are Asked. Ottawa: Statistics Canada.

—. 1996. 1996 Census Guide and Reasons Why the Questions are Asked. Ottawa: Statistics Canada. . 1998. 1996 Census: Ethnic Origin, Visible Minorities. The Daily (Ottawa: Statistics Canada), February 17.

-2001. Census Guide 2001. Ottawa: Statistics Canada.

-2006. Census Guide 2B 2006 (long form). Ottawa: Statistics Canada.

-2008. Canada's Ethnocultural Mosaic: 2006 Census. Ottawa, Statistics Canada

- 2013. Immigration and Ethnocultural Diversity in Canada: National Household Survey, 2011. Ottawa: Statistics Canada.

Tafoya, S.M., H. Johnson, and L. Hill. 2005. Who chooses to choose two? In The American People: Census 2000, edited by R. Farley and J. Haaga. New York: Russell Sage Foundation. p. 332-351.

Thomas, D. 2005. "T am Canadian:” Canadian Social Trends. Statistics Canada Catalogue No. 11-008. Ottawa: Statistics Canada.

Thompson, D. 2012. Making (mixed-)race: Census politics and the emergence of multiracial multiculturalism in the United States, Great Britain and Canada. Ethnic and Racial Studies 35(8):1409-1426.

United Nations. 2011. Ethnocultural Characteristics. Vol. 2013, article May 29. Available online at: http:/ / unstats.un.org/unsd/demographic/sconcerns/popchar/popcharmethods.htm.

US Census Bureau. 1992. 1990 Census of Population: Detailed Ancestry Groups for States. Washington: US Census Bureau.

-2002. Measuring America: The Decennial Censuses from 1790 to 2000. Washington: US Census Bureau.

Wallman, K.K. 1998. Data on race and ethnicity: revising the federal standard. American Statistician 52:31-33.

Yanow, D. 2002. Constructing 'Race' and 'Ethnicity' in America: Category-Making in Public Policy and Administration. Armonk NY: M.E. Sharpe. 